\section{M \\ VIA MEDICA \\ www.fr.viamedica.pl}

\title{
Humor i śmiech jako metody terapeutyczne
}

\section{Humour and laughter as therapeutic tools}

\section{STRESZCZENIE}

Humor i śmiech od dawna są uważane za czynniki sprzyjające zdrowiu. Dopiero jednak w drugiej potowie XX wieku rozpoczęto badania fizjologicznych skutków humoru i śmiechu oraz możliwości ich zastosowania w lecznictwie. Opisano wiele korzystnych efektów humoru i śmiechu, w tym rozszerzenie naczyń, zmiany tętna i ciśnienia tętniczego krwi, a także zmiany immunologiczne, takie jak zmniejszenie stężenia w surowicy interleukiny- 6 u chorych na reumatoidalne zapalenie stawów. Są to jednak tylko krótkotrwałe skutki. Nie zmienia to faktu, że poprawa nastroju, tak zwany dobry humor i śmiech, są pożądane, jako działania pomocnicze w procesie leczenia wielu chorób.

Forum Reumatol. 2019, tom 5, nr 2: 74-80

Słowa kluczowe: humor; śmiech; leczenie

\section{WSTĘP}

Powszechnie przyjmuje się, że dobry nastrój, pogodny humor czy wesoły śmiech sprzyjają zdrowiu. Przekonanie to wyraża kilka powiedzeń, chociażby najbardziej znane: „śmiech to zdrowie". Jest to, jak można by przyjąć, prawda oczywista. Mimo aksjomatycznego uznania humoru i śmiechu za czynniki wspierające pozytywnie zdrowie, nawet w kręgach medycznych, mało jest znane zastosowanie humoru i śmiechu w leczeniu. Naukowe i racjonalne podejście do tych zagadnień jest ciągle zaskoczeniem dla wielu lekarzy. Przedmiotem przedstawionego opracowania jest zestawienie naukowych danych dotyczących zastosowania humoru jako metody terapeutycznej.

Adres do korespondencji: prof. dr hab. n. med. Eugeniusz Józef Kucharz Katedra i Klinika Chorób Wewnętrznych,

Reumatologii i Immunologii Klinicznej

Śląskiego Uniwersytetu

Medycznego w Katowicach e-mail: ejkucharz@poczta.onet.pl

\section{HUMOR I ŚMIECH JAKO TEMAT BADAŃ NAUKOWYCH}

Nie trudno sobie wyobrazić, że już od dawna intuicyjnie wyczuwano pozytywną rolę dobrego humoru w utrzymaniu lub przywracaniu zdrowia. Licząca ponad trzy tysiące lat Księga Przysłów, wchodząca w skład Starego
Testamentu, zawiera stwierdzenie: „Radość serca wychodzi na zdrowie, duch przygnębiony wysusza kości” (Księga Przysłów 17:22). Lekarze starożytnej Grecji, a także medycyna ludowa Indian zalecali śmiech w procesie zdrowienia [1, 2]. Szeroko pojętą wesołość polecał francuski lekarz de Mondeville (ok. 12601320) w zwalczeniu bólu pooperacyjnego, o czym pisał w swym dziele „Cyrurgia”. Humor w leczeniu chorób psychicznych zalecał angielski humanista Robert Burton (1577-1640), co opisał w swojej książce „The Anatomy of Melancholy" (1621). Dopiero jednak w drugiej połowie XX wieku rozpoczęto badania naukowe omawianego tematu i stworzono termin „gelotologia”, czyli nauka o śmiechu [2].

W latach 70. XX wieku rozpoczęły się badania psychoneuroimmunologiczne. Lee S. Berk (Loma Linda University, Kalifornia, Stany Zjednoczone) badał patofizjologię humoru i stworzył pojęcie „eustressu” jako pozytywnego i korzystnego dla organizmu stanu emocjonalnego. Wiliam F. Fry jr (1924-2014) ze Stanford University opisał jako pierwszy wiele zjawisk somatycznych towarzyszących śmiechowi, a w 1964 roku utworzył pierw- 
szy Instytut Gelotologii. Robert R. Provine z University of Maryland analizował aspekty behawioralne śmiechu. Lecznicze zastosowanie humoru badał Hunter Adams (1945-). To oczywiście tylko wybrane nazwiska pionierów gelotologii. Należy dodać to tego badania psychologiczne i zastosowanie humoru w nauczaniu. Humor i śmiech stały się zjawiskami poważnie potraktowanymi przez naukę. Powstało prestiżowe Międzynarodowe Towarzystwo Badania Humoru (International Society of Humor Research) założone w 1980 roku, organizowane są kongresy naukowe na ten temat, a także ukazuje się czasopismo „International Journal of Humor Studies”. W Polsce, oprócz kilku wydawnictw i kilku konferencji naukowych, prowadzony jest projekt „Humour Research Project".

\section{DEFINICJA I OGÓLNE TEORIE HUMORU I ŚMIECHU}

Humor jest zjawiskiem wielowymiarowym, niemającym jednej całościowej definicji. Może być rozpatrywany w aspekcie socjologicznym, czyli komunikacji międzyludzkiej. Może być rozumiany jako psychologiczny mechanizm obronny, a także jako proces fizjologiczny regulujący lub normalizujący zjawiska wywołane w naszym organizmie przez stres [3].

Humor może być też rozpatrywany jako indywidualna cecha osobowości rozumiana jako poczucie humoru lub „wesoła osobowość", czyli predyspozycja do odbioru lub wysyłania specyficznych komunikatorów wywołujących wesołość. W określeniu humoru niekiedy wyróżnia się takie aspekty, jak zdolność odbierania sygnałów humorystycznych („rozumienie i pozytywne reakcje na usłyszany dowcip”), zdolność do ekspresji i zdolność do uwypuklania wesołości w otaczającej rzeczywistości, czyli umiejętność na przykład humorystycznego skomentowania zaistniałej sytuacji. Do tego dochodzą takie cechy, jak umiejętność wyszukiwania zabawnych sytuacji, ich zapamiętywania i zdolność przekazywania ich innym tak, aby wywoływać wesołość [4]. Należy dodać, że osoby z wysokim poziomem humoru posiadają zdolność wykorzystywania go do zmniejszenia stresu. Można też przyjąć bardziej ogólną koncepcję humoru, zaproponowaną przez Longa i Graessera [5] jako „wszystko co zostało uczynione lub powiedziane, celowo lub przypadkowo, a jest odbierane jako komiczne lub zabawne”. Humor można klasyfikować (np. na werbalny i niewerbalny), ma on aspekt historyczny (to co śmieszyło kiedyś, teraz nie musi być odbierane jako śmieszne) i kulturowy [3].

Śmiech jest behawioralną ekspresją humoru, a raczej jest wywołany przez humor i ma określone formy ekspresji i swój aspekt patofizjologiczny. Ruch i Ekman [6] zdefiniowali śmiech jako głosowy ekspresywno-komunikatywny sygnał mający określony wymiar głosowy, oddechowy, dotyczący wyrazu twarzy, ruchów całego ciała i towarzyszących zjawisk czynnościowych.

Humor można wyjaśnić, opierając się na kilku teoriach. Ich omówienie wykracza poza ramy niniejszego opracowania. Wspomnieć jedynie należy o trzech podstawowych teoriach humoru. Należy do nich teoria ,niedorzeczności” (incongruity). Jej podstawą jest założenie, że śmieszne jest to, co nie pasuje do naszych „standardowych” wyobrażeń o rzeczywistości. Teoria ta tłumaczy wiele sytuacji humorystycznych, ale nie pozwala na wyjaśnienie, dlaczego niektóre „nieoczekiwane” lub „nietypowe” sytuacje są śmieszne, a inne nie budzą wesołości.

Inna teoria zakłada, że humor jest mechanizmem obronnym, homeostatycznym i chroniącym przez uszkodzeniami spowodowanym przez stres. Jest to zgodne $z$ teorią pobudzenia. Freud (1856-1938) uważał, że humor uwalnia „nadmiar” energii nerwowej, która w danym momencie maskuje inne motywy lub pożądania (wg [4]).

Do opisanych teorii należy dodać teorię wyższości. Śmiejąc się z innych, w pewien sposób wywyższamy się ponad nich. Przykładowo, większą wesołość budzą żarty z ludzi, w stosunku do których mamy negatywne nastawienie [4].

\section{PATOFIZJOLOGIA HUMORU I ŚMIECHU}

Opisano wiele reakcji fizjologicznych związanych ze śmiechem i humorem. Już wczesne prace Fryego wykazały zmiany wentylacji, czynności mięśni, ciśnienia krwi, tętna itp. podczas śmiechu lub pod wpływem wesołych sytuacji [7]. Dużo uwagi poświęcono aktywacji osi podwzgórze-przysadka mózgowa-nadnercza. Wykazano, że humor zmniejsza stężenie kortyzolu i katecholamin. Humor zwiększa uwalnianie oksytocyny, a także endorfin — naturalnych agonistów receptorów opioidowych [2]. Toda i wsp. [8, 9] wykazali, że oglądanie komedii filmowej łączy się ze zwiększeniem stężenia chromogeniny A — wskaźnika stresu w ślinie, podczas gdy oglądanie niekomicznego filmu nie daje takiego efektu. Opisane zmia- 
ny były bardziej zaznaczone u osób z niskim wyjściowym (przed filmem) poziomem stresu. W kolejnej pracy porównali grupę osób młodych i starych, które najpierw rozwiązywały zadania arytmetyczne, a potem oglądały film komediowy. Stres rozwiązywania zadań arytmetycznych u ludzi starszych łączył się ze zmniejszonym wydzielaniem śliny. Nie zmieniał się istotnie podczas oglądania komedii. U ludzi młodych nie stwierdzono zmian ilości wydzielanej śliny ani podczas rozwiazywania zadań arytmetycznych, ani podczas oglądania komedii. Stężenie chromograniny A w ślinie zwiększyło się bezpośrednio po rozwiązywaniu zadań, a zmniejszyło się 60 minut po wykonaniu zadania. Zmniejszenie stężenia wskaźnika stresu obserwowano u młodych osób podczas oglądania komedii. U osób starszych nie zaobserwowano zmian stężenia chromograniny A w ślinie ani podczas rozwiązywania zadań arytmetycznych, ani oglądania komedii.

Ciekawe są zmiany immunologiczne. Berg i wsp. [10] wykazali, że śmiech zwiększa aktywność komórek typu „natural killer”, co może mieć związek z pewną opornością na rozwój nowotworzenia. Potwierdziły to zjawisko późniejsze prace [2].

Wpływ 15 minut słuchania i oglądania (wideo) programu złożonego z 14 epizodów komicznych na ciśnienie tętnicze krwi wykazał, że śmiech (a także śmiech stymulowany) łączy się z przejściowym zwiększaniem ciśnienia tętniczego, po czym dochodzi do jego zmniejszenia poniżej ciśnienia odnotowanego przed ekspozycją na epizody komiczne [11].

Wykazano, że oglądanie wesołych programów aktywuje układ antyoksydantów [12, 13]. $Z$ innych efektów humoru należy wspomnieć o działaniu zmniejszającym napięcie mięśni szkieletowych [14], zwiększanie progu odczuwania bólu i poprawę czynności umysłowych [2].

\section{TERAPEUTYCZNE ZASTOSOWANIE HUMORU}

Ogłoszono dość liczne prace wskazujące na korzystne lecznicze działanie humoru. Niektóre z nich mogą być podstawą programów leczniczych uzupełniajacych inne metody terapeutyczne lub zmniejszające towarzyszące im działania niepożądane. W badaniach tych należy zróżnicować humor (rozumiany jako przykładowo oglądanie komedii lub słuchanie rozweselających historii) od śmiechu, jako wyrazu humoru spontanicznego lub tylko śmiechu stymulowanego.

\section{KLOWN* W SZPITALU DZIECIĘCYM}

Pobyt w szpitalu, oczekiwanie na zabieg chirurgiczny, a także sama choroba są znaczącym stresem, szczególnie dla dzieci, dla których wiele przykrych doznań pozostaje niezrozumiałymi. Jedną z metod zmniejszenia lęku i stresu wyżej opisanego jest działalność „doktorów klownów” rozwijająca się w wielu krajach, w tym w Polsce. Ta forma działalności została zapoczątkowana w 1986 roku w Stanach Zjednoczonych przez zawodowego klowna Michaela Christensena [15]. Z czasem powstały zespoły lub grupy (Clown Care Units) złożone z klownów, popularnie nazywanych „doktorami klownami” (clown doctors), którzy organizują pokazy i drobne zabawy dla chorych dzieci. Ostatnie dwie dekady przyniosły wiele wyników badań mocno wskazujących na skuteczność opisywanego postępowania w łagodzeniu lęku i bólu. Spotkanie z doktorem klownem pomaga także przerwać błędne koło, jakim jest lęk przed zabiegiem uwarunkowany pamięcią wcześniejszych przykrych doznań w szpitalu. Już w 2005 roku grupa pediatrów włoskich wykazała, że spotkanie z klownami zmniejsza lęk u dzieci hospitalizowanych [16]. Potwierdziły to dalsze prace z różnych krajów [17]. Podobne spotkanie z klownami zmniejsza odczuwanie bólu. Wykazano to szczególnie u dzieci w wieku 4-7 lat poddanych takim procedurom, jak zakładanie wenflonu lub wstrzyknięcia dostawowe [18, 19].

Podsumowując, działalność „doktorów klownów" oddziałuje pozytywnie w postaci skutków kognitywnych (oderwanie myśli dzieci od spraw medycznych), fizjologicznych (uwalnianie endorfin, zmniejszenie odczuwania bólu, ogólna relaksacja), społecznych (poczucie współdziałania dziecka i klowna) oraz emocjonalnych (pozytywne myślenie, opanowanie lęku) [18].

W Polsce działa od 1999 roku Fundacja Dr Clown, która pomaga chorym dzieciom w szpitalach i placówkach specjalnych, dając im radość i wesołość.

W Europie działa European Federation of Hospital Clown Organizations (EFHCO) założona w 2011 roku. Liczne są organizacje narodowe, takie jak Féderation Française des Associations de Clowns Hospitaliers czy Canadian Association of Therapeutic Clowns.

*W pracy przyjęto pisownię klown, podaną przez Stownik Języka Polskiego i równorzędną z pisownią klaun lub clown. 


\section{LECZNICZY WPEYW HUMORU W POSZCZEGÓLNYCH CHOROBACH}

W literaturze medycznej ostatnich lat można znaleźć kilkadziesiąt raczej dobrze udokumentowanych prac dotyczących roli humoru w leczeniu różnych chorób. Choroby, w których próbowano zastosować wspomagającą terapię humorem są jednak bardzo zróżnicowane i trudno jest przeprowadzić systematyczną analizę problemu. Różne są też grupy wiekowe badanych pacjentów. Niestety, większość badań dotyczyła małych grup chorych.

Zastosowanie śmiechu w reumatologii było przedmiotem kilku prac naukowych. Już w 1996 roku Yoshino i wsp. [20] i Nakajima i wsp. [21] w 1999 roku wykazali wiele zmian biochemiczno-immunologicznych zachodzących u chorych na reumatoidalne zapalenie stawów pod wpływem śmiechu. Zmiany te prowadziły do zmniejszenia aktywności choroby, niestety trwającego krótko. Ta sama grupa badaczy wykazała, że zwiększone stężenie hormonu wzrostu u chorych na reumatoidalne zapalenie stawów znacząco się zmniejsza po epizodzie śmiechu. Nie stwierdzono natomiast różnic w stężeniu substancji P [22].

Kolejnym studium wspomnianej grupy z tokijskiej Nippon Medical School była praca wskazująca na zmniejszenie stężenia interleukiny-6 u chorych przez godzinę słuchających tradycyjnych japońskich opowieści komicznych (Rakugo). Zjawiska tego nie obserwowano w grupie osób zdrowych o prawidłowym wyjściowym stężeniu interleukiny-6. U chorych $\mathrm{z}$ mniejszym nasileniem procesu zapalnego obserwowano również zmniejszenie stężenia czynnika martwicy nowotworów $\alpha$ (TNF- $\alpha$, tumor necrosis factor $\alpha$ ) pod wpływem śmiechu. Opisano również zmiany stężenia przeciwzapalnej interleukiny-4 [23]. Niestety, obserwacje korzystnego działania śmiechu ograniczyły się do badania bezpośrednio po ekspozycji na treści humorystyczne i brak jest danych o skutkach powtarzanych epizodów śmiechu.

Moura i wsp. [24] w 2015 roku próbowali zastosować 120-minutową ekspozycję na materiały rozweselające $u$ chorych na układowy toczeń rumieniowaty. Nie wykazali zmian stężeń kilku pozapalnych cytokin. Jedyną obserwacją wskazującą na rolę śmiechu była sugestia zmniejszonego wydzielania kortyzolu u chorych oglądających komedię.

Wspomnieć należy o działaniu śmiechu zmniejszającym napięcie mięśni szkieleto- wych, a dokonującym się poprzez zmniejszoną stymulację mięśni z rdzenia kręgowego trwająca do 45 minut po zakończeniu śmiechu [14]. Może to łączyć się z działaniem przeciwbólowym u chorych na chorobę zwyrodnieniową stawów.

Kilka badań dotyczyło wpływu śmiechu na układ sercowo-naczyniowy i jego choroby. W przeciwieństwie do negatywnych emocji i zmian nastroju, takich jak depresja lub lęk, które są dość dobrze poznane w chorobach serca i naczyń, śmiech był dużo rzadziej przedmiotem badań. Wpływ śmiechu na sztywność ściany tętnic i czynność śródbłonka po raz pierwszy badał Vlachopoulos i wsp. [25] w 2009 roku. Rok później Sugawara i wsp. [26] wykazali, że oglądanie komedii (30 min) w przeciwieństwie do filmu dokumentalnego (30 min) zwiększa szerokość tętnicy ramiennej w teście jej niedokrwienia, a także zwiększa elastyczność tętnicy szyjnej oraz przyspiesza akcję serca. Sugerowano różne mechanizmy tego zjawiska (m.in. uwalnianie tlenku azotu) [27]. Law i wsp. [28] porównali spontaniczny i stymulowany śmiech, wykazując, że oba rodzaje śmiechu zwiększają akcję serca, przy czym śmiech stymulowany może być bardziej efektywny, bo jak to określają badacze jest „większą dawką śmiechu”. Dość liczne są też prace wskazujące na rolę nastroju w przebiegu chorób serca, ale nie dotyczą one zastosowania leczniczego śmiechu. Uważa się jednak, że efekty humoru i śmiechu na ciśnienie tętnicze krwi są krótkotrwałe i nie mają odległych pozytywnych skutków.

Choroby nowotworowe ze zrozumiałych względów stanowią szczególne obciążenie psychiki chorego. Dlatego opisano wiele aspektów stosowania humoru i śmiechu jako terapii wspomagającej u chorych onkologicznych. Humor jest też zalecany pracownikom oddziałów onkologicznych dla ich ochrony przed stresem [29]. Wiele obserwacji wskazuje na korzystne działanie humoru u chorych na nowotwory [30-32], a czynione były nawet próby zastosowania humoru jako terapii wspomagającej odporność u chorych na nowotwory [33].

Nie wykazano istotnych, dłużej trwających, zmian czynności oddechowych pod wpływem śmiechu. Sam śmiech może łączyć się z pogłębieniem oddychania. Pamiętać trzeba, że u chorych na astmę śmiech może prowokować skurcz oskrzeli. Sugestie o korzystnym wpływie humoru na stan chorych na przewlekłą chorobę obturacyjną płuc nie zostały potwierdzone [34]. 
Opisano kilka kontrolowanych badań dotyczących roli śmiechu i humoru w innych chorobach. Ze względu na rolę śmiechu w regulacji zjawisk immunologicznych [35] wykazano korzystną rolę w atopowym zapaleniu skóry i inne choroby alergiczne $[36,37]$. $U$ chorych na cukrzycę typu 2 śmiech zmniejsza poposiłkowe stężenie glukozy i wydaje się być czynnikiem zapobiegającym rozwojowi powikłań [38, 39].

$\mathrm{Z}$ innych zagadnień medycznych związanych ze śmiechem należy wskazać jego rolę $\mathrm{w}$ leczeniu chorych dializowanych [40, 41]. Wykazano korzystne działanie śmiechu (lub tzw. śmiechu symulowanego) na nastrój i jakość życia chorych dializowanych. Istotne jest także zmniejszenie lęku, jaki może towarzyszyć dializom. U ludzi starszych wykazano korzystne działanie humoru i śmiechu na sprawność umysłową [42-44]. Szczególnie przydatna okazała się tak zwana laughter yoga będąca kombinacją spontanicznego śmiechu z technikami oddychania [45]. Odrębnym zagadnieniem jest zastosowanie terapeutyczne humoru i śmiechu w psychiatrii i psychologii, a także w optymalizacji nauczania. Wykracza to jednak poza główny temat przedstawionej pracy.

\section{PODSUMOWANIE}

Przedstawione badania podchodzą poważnie do tematu, jakim jest humor i śmiech. Dostarczają one udokumentowania wielu skutków fizjopatologicznych, psychologicznych, a także socjalnych śmiechu u osób zdrowych i chorych. Nie wydaje się jednak, aby procedury te same w sobie były wystarczające do leczenia. Ich zastosowanie pomocnicze jest w pełni uzasadnione i celowe, a w niektórych działaniach medycyny dobrze sprawdzone (pediatria). Podsumowując, ważne jest nie tyle zalecanie śmiechu jako metody leczniczej, ile unikanie jej niezamierzonego codziennego stosowania, czemu, niestety, sprzyja stres lekarzy i pozostałego personelu medycznego, brak czasu przeznaczonego na rozmowę z chorym, a także trudności organizacyjne ochrony zdrowia. Stara prawda mówiąca, że osobowość lekarza jest też ważnym lekiem ma zastosowanie również w tym aspekcie. Trudno więc w naszych warunkach zalecać planowe stosowanie humoru w lecznictwie, ale zawsze jak pojawią się okoliczności pozwalające na „propagowane radosnego nastroju” u naszych chorych, to na pewno zasługują one na poparcie i kontynuację.

\section{ABSTRACT}

Humour and laughter have long been considered as beneficial for health. Development of scientific research on physiological effects of humour and laughter, and the possibility of their application in therapy began in the second half of the 20th century. A number of beneficial effects of humour and laughter were reported, including vasodilation, changes in heart rate and blood pressure and immune phenomena such as reduction of the serum level of interleukin- 6 in patients with rheumatoid arthritis. However, all these findings referred to only short-term effects. This does not change the fact that the improving mood, good humour and laughter are desirable as supplementary activities in the process of treatment of many diseases.

Forum Reumatol. 2019, tom 5, nr 2: 74-80

Key words: humor; laughter; treatment

\section{Piśmiennictwo}

1. Kleisiaris CF, Sfakianakis C, Papathanasiou IV. Health care practices in ancient Greece: The Hippocratic ideal. $\mathrm{J}$ Med Ethics Hist Med. 2014; 7: 6, indexed in Pubmed: 25512827.

2. Savage BM, Lujan HL, Thipparthi RR, et al. Humor, laughter, learning, and health! A brief review. Adv Physiol Educ. 2017; 41(3): 341-347, doi: 10.1152/advan.00030.2017, indexed in Pubmed: 28679569.

3. Rusek A. Wielowymiarowość humoru. Innowacje Psychologiczne. 2012; 1: 117-127.

4. Scheel T. Definitions, theories and measurement of humor. In: Scheel T, Gockel C. ed. Humor at work in teams, leader- ship, negotiations, learning and health. Springer Briefs in Psychology, Springer, Berlin 2017: 9-29.

5. Long D, Graesser A. Wit and humor in discourse processing. Discourse Processes. 1988; 11(1): 35-60, doi: 10.1080/01638538809544690.

6. Ruch W, Ekman P. The expressive pattern of laughter. In: Kaszniak AW. ed. Emotion, qualia, and consciousness. World Scientific Publishers, Tokyo 2001: 426-443.

7. FRY W. The biology of humor. Humor - International Journal of HumorResearch. 1994; 7(2), doi: 10.1515/humr.1994.7.2.111.

8. Toda M, Kusakabe S, Nagasawa S, et al. Effect of laughter on salivary endocrinological stress marker chromogranin 
A. Biomed Res. 2007; 28(2): 115-118, indexed in Pubmed: 17510497.

9. Toda M, Ichikawa $\mathrm{H}$. Effect of laughter on salivary flow rates and levels of chromogranin A in young adults and elderly people. Environ Health Prev Med. 2012; 17(6): 494-499, doi: 10.1007/s12199-012-0279-5, indexed in Pubmed: 22481535.

10. Berk LS, Felten DL, Tan SA, et al. Modulation of neuroimmune parameters during the eustress of humor-associated mirthful laughter. Altern Ther Health Med. 2001; 7(2): 62-72, 74, indexed in Pubmed: 11253418.

11. Mora-Ripoll R. Potential health benefits of simulated laughter: a narrative review of the literature and recommendations for future research. Complement Ther Med. 2011; 19(3): 170-177, doi: 10.1016/j.ctim.2011.05.003, indexed in Pubmed: 21641524.

12. Atsumi T, Tonosaki K, Fujisawa S. Salivary free radical-scavenging activity is affected by physical and mental activities. Oral Dis. 2008; 14(6): 490-496, doi: 10.1111/j.1601-0825.2007.01406.x, indexed in Pubmed: 18826379.

13. Miller M, Fry WF. The effect of mirthful laughter on the human cardiovascular system. Med Hypotheses. 2009; 73(5): 636-639, doi: 10.1016/j.mehy.2009.02.044, indexed in Pubmed: 19477604.

14. Bennett MP. Health benefits of humor, physical. In: Attardo SP. ed. Encyclopedia of humor studies. Saga, Los Angeles 2014: 277-280.

15. Dionigi A. Clowning as a Complementary Approach for Reducing latrogenic Effects in Pediatrics. AMA J Ethics. 2017; 19(8): 775-782, doi: 10.1001/journalofethics.2017.19.8.stas1-1708, indexed in Pubmed: 28846517

16. Vagnoli L, Caprilli S, Robiglio A, et al. Clown doctors as a treatment for preoperative anxiety in children: a randomized, prospective study. Pediatrics. 2005; 116(4): e563-e567, doi: 10.1542/peds.2005-0466, indexed in Pubmed: 16199685

17. Koller D, Gryski C. The life threatened child and the life enhancing clown: towards a model of therapeutic clowning. Evid Based Complement Alternat Med. 2008; 5(1): 17-25, doi: 10.1093/ecam/nem033, indexed in Pubmed: 18317544.

18. Wolyniez I, Rimon A, Scolnik D, et al. The effect of a medical clown on pain during intravenous access in the pediatric emergency department: a randomized prospective pilot study. Clin Pediatr (Phila). 2013; 52(12): 1168-1172, doi: $10.1177 / 0009922813502257$, indexed in Pubmed: 24028842.

19. Weintraub Y, Rabinowicz N, Hanuka P, et al. Medical clowns facilitate nitrous oxide sedation during intra-articular corticosteroid injection for juvenile idiopathic arthritis. Isr Med Assoc J. 2014; 16(12): 771-773, indexed in Pubmed: 25630207.

20. Yoshino S, Fujimori J, Kohda M. Effects of mirthful laughter on neuroendocrine and immune systems in patients with rheumatoid arthritis. J Rheumatol. 1996; 23(4): 793-794, indexed in Pubmed: 8730156.

21. Nakajima A, Hirai H, Yoshino S. Reassessment of mirthful laughter in rheumatoid arthritis. J Rheumatol. 1999; 26(2): 512-513, indexed in Pubmed: 9973000.

22. Ishigami S, Nakajima A, Tanno M, et al. Effects of mirthful laughter on growth hormone, IGF-1 and substance $\mathrm{P}$ in patients with rheumatoid arthritis. Clin Exp Rheumatol. 2005; 23(5): 651-657, indexed in Pubmed: 16173241.
23. Matsuzaki T, Nakajima A, Ishigami S, et al. Mirthful laughter differentially affects serum pro- and anti-inflammatory cytokine levels depending on the level of disease activity in patients with rheumatoid arthritis. Rheumatology (Oxford). 2006; 45(2): 182-186, doi: 10.1093/rheumatology/kei081, indexed in Pubmed: 16319105.

24. Moura CS, Li R, Lawrie $S$, et al. Humor in systemic lupus erythematosus. Eur J Rheumatol. 2015; 2(1): 5-9, doi: 10.5152/eurjrheumatol.2015.0070, indexed in Pubmed: 27708912.

25. Vlachopoulos C, Xaplanteris P, Alexopoulos N, et al. Divergent effects of laughter and mental stress on arterial stiffness and central hemodynamics. Psychosom Med. 2009; 71(4): 446-453, doi: 10.1097/PSY.0b013e318198dcd4, indexed in Pubmed: 19251872.

26. Sugawara J, Tarumi T, Tanaka H. Effect of mirthful laughter on vascular function. Am J Cardiol. 2010; 106(6): 856-859, doi: 10.1016/j.amjcard.2010.05.011, indexed in Pubmed: 20816128.

27. Boone T, Hansen S, Erlandson A. Cardiovascular responses to laughter: a pilot project. Appl Nurs Res. 2000; 13(4): 204-208, doi: 10.1053/apnr.2000.7656, indexed in Pubmed: 11078786 .

28. Law MM, Broadbent EA, Sollers JJ. A comparison of the cardiovascular effects of simulated and spontaneous laughter. Complement Ther Med. 2018; 37: 103-109, doi: 10.1016/j.ctim.2018.02.005, indexed in Pubmed: 29609921.

29. Simon JM. Humor techniques for oncology nurses. Oncol Nurs Forum. 1989; 16(5): 667-670, indexed in Pubmed: 2780403.

30. Kim SoH, Kook JR, Kwon M, et al. The effects of laughter therapy on mood state and self-esteem in cancer patients undergoing radiation therapy: a randomized controlled trial. J Altern Complement Med. 2015; 21(4): 217-222, doi: 10.1089/acm.2014.0152, indexed in Pubmed: 25875938.

31. van Dorn A. Laughter is the best form of therapy. Lancet Oncol. 2015; 16(16): 1601, doi: 10.1016/S14702045(15)00496-9, indexed in Pubmed: 26678191.

32. Christie $\mathrm{W}$, Moore $\mathrm{C}$. The impact of humor on patients with cancer. Clin J Oncol Nurs. 2005; 9(2): 211-218, doi: 10.1188/05.CJON.211-218, indexed in Pubmed: 15853164

33. Sakai $\mathrm{Y}$, Takayanagi $\mathrm{K}, \mathrm{Ohno} \mathrm{M}$, et al. A trial of improvement of immunity in cancer patients by laughter therapy. Jpn Hosp. 2013(32): 53-59, indexed in Pubmed: 23984543.

34. Lebowitz KR, Suh S, Diaz PT, et al. Effects of humor and laughter on psychological functioning, quality of life, health status, and pulmonary functioning among patients with chronic obstructive pulmonary disease: a preliminary investigation. Heart Lung. 2011; 40(4): 310-319, doi: 10.1016/..hrtlng.2010.07.010, indexed in Pubmed: 21724041.

35. Chang C, Tsai G, Hsieh CJ. Psychological, immunological and physiological effects of a Laughing Qigong Program (LQP) on adolescents. Complement Ther Med. 2013; 21(6): 660-668, doi: 10.1016/j.ctim.2013.09.004, indexed in Pubmed: 24280475.

36. Kim S, Kim SJ, Dukyoo J, et al. The Effects of a Humor Intervention on the Physiological, Physical, and Psychological Responses of School-aged Children With Atopic Dermatitis in South Korea: A Pilot Study. J Pediatr Nurs. 2018; 39: e21-e29, doi: 10.1016/.jpedn.2018.01.001, indexed in Pubmed: 29398317. 
37. Sim InOk. Humor intervention program for children with chronic diseases. Appl Nurs Res. 2015; 28(4): 404-412, doi: 10.1016/j.apnr.2015.09.001, indexed in Pubmed: 26608447.

38. Hayashi T, Murakami K. The effects of laughter on post-prandial glucose levels and gene expression in type 2 diabetic patients. Life Sci. 2009; 85(5-6): 185-187, doi: 10.1016/j.lfs.2009.05.002, indexed in Pubmed: 19450597.

39. Noureldein MH, Eid AA. Homeostatic effect of laughter on diabetic cardiovascular complications: The myth turned to fact. Diabetes Res Clin Pract. 2018; 135: 111-119, doi: 10.1016/j.diabres.2017.11.014, indexed in Pubmed: 29162513.

40. Ganz FD, Jacobs JM. The effect of humor on elder mental and physical health. Geriatr Nurs. 2014; 35(3): 205-211, doi: 10.1016/j.gerinurse.2014.01.005, indexed in Pubmed: 24656050.

41. Bennett PN, Parsons T, Ben-Moshe R, et al. Laughter and humor therapy in dialysis. Semin Dial. 2014; 27(5):
488-493, doi: 10.1111/sdi.12194, indexed in Pubmed: 24467450.

42. Gonot-Schoupinsky FN, Garip G. Laughter and humour interventions for well-being in older adults: A systematic review and intervention classification. Complementary Therapies in Medicine. 2018; 38: 85-91, doi: 10.1016/j. ctim.2018.04.009.

43. Ripoll RM, Casado IQ. Laughter and positive therapies: modern approach and practical use in medicine. Rev Psiquiatr Salud Ment. 2010; 3(1): 27-34, doi: 10.1016/S18889891(10)70006-9, indexed in Pubmed: 23017490.

44. Ganz FD, Jacobs JM. The effect of humor on elder mental and physical health. Geriatr Nurs. 2014; 35(3): 205-211, doi: 10.1016/j. gerinurse.2014.01.005, indexed in Pubmed: 24656050.

45. Shahidi M, Mojtahed A, Modabbernia A, et al. Laughter yoga versus group exercise program in elderly depressed women: a randomized controlled trial. Int J Geriatr Psychiatry. 2011; 26(3): 322-327, doi: 10.1002/gps.2545, indexed in Pubmed: 20848578. 